ББК 63.4

\author{
Организация конференциии и издание материалов проведень \\ при финансовой поддержке Российского фонда фундаментальных исследований, \\ проект № 19-09-20008
}

Утверждено к печати Ученым советом ИИМК РАН

Редакционная коллегия тома I: В. А. Алёкшин, Л. Б. Кирчо (отв. редакторы),

В. П. Никоноров, В. Я. Стёганцева; В. В. Терёхина

Рецензенты: д. и. н. Л. Б. Вишняцкий, д. и. н. А. А. Выборнов

Программный комитет конференции: академик РАН, д. и. н., проф. М. Б. Пиотровский

(Государственный Эрмитаж, почетный председатель); д. и. н. В. А. Лапшин (ИИМК РАН, председатель); д. и. н. А. В. Головнёв (МАЭ РАН, сопредседатель); д. и. н. В. А. Дергачёв (Высшая антропологическая школа, Молдова, сопредседатель); д. и. н. И. Ф. Попова (ИВР РАН, сопредседатель); академик АН Республики Узбекистан, д. и. н., проф. Э. В. Ртвеладзе (сопредседатель); к. и. н. А. В. Поляков (ИИМК РАН, зам. председателя); к. и. н. В. А. Алёкшин (ИИМК РАН, зам. председателя); д. и. н. Ю. Е. Берёзкин (МАЭ РАН); Dr., Prof. Н. Бороффка (Германский археологический институт, Германия); В. С. Бочкарёв (ИИМК РАН); Dr. Э. Кайзер (Свободный университет Берлина, Германия); к. и. н. М. Т. Кашуба (ИИМК РАН); д. и. н. Л. Б. Кирчо (ИИМК РАН); к. и. н. А. В. Кияшко (Южный федеральный университет); к. и. н. П. Ф. Кузнецов (СГСПУ);

к. и. н. Н. М. Малов (СНИГУ); к. и. н. В. П. Никоноров (ИИМК РАН); Ю. Ю. Пиотровский

(Государственный Эрмитаж); д. и. н., проф. Д. Г. Савинов (Институт истории СПбГУ);

к. и. н. В. Н. Седых (Институт истории СПбГУ); к. и. н. Н. Н. Скакун (ИИМК РАН);

к. и. н. Н. Ф. Соловьёва (ИИМК РАН); к. и. н. А. И. Торгоев (Государственный Эрмитаж); к. и. н. Е. А. Черлёнок (Институт истории СПбГУ)

Организационный комитет конференции: к. и. н. А. В. Поляков (ИИМК РАН, председатель);

к. и. н. В. А. Алёкшин (ИИМК РАН, зам. председателя); В. С. Бочкарёв (ИИМК РАН); ); к. и. н. М. Т. Кашуба (ИИМК РАН); д. и. н. Л. Б. Кирчо (ИИМК РАН);

А. И. Климушина (ИИМК РАН, отв. секретарь); к. и. н. В. П. Никоноров (ИИМК РАН); Ю. Ю. Пиотровский (Государственный Эрмитаж); В. Я. Стёганцева (ИИМК РАН); В. В. Терёхина

(ИИМК РАН, МАЭ РАН, отв. секретарь); к. и. н. Е. С. Ткач (ИИМК РАН); И. Ж. Тутаева (Государственный Эрмитаж); к. и. н. Е. А. Черлёнок (Институт истории СПбГУ)

Древности Восточной Европы, Центральной Азии и Южной Сибири в контексте связей и взаимодействий в евразийском культурном пространстве (новые данные и концепции): Материалы Международной конференции, 18-22 ноября 2019 г., Санкт-Петербург. Т. I. Древняя Центральная Азия в контексте евразийского культурного пространства (новые данные и концепции). К 90-летию со дня рождения патриарха евразийской археологии Вадима Михайловича Массона. - СПб.: ИИМК РАН, Невская Типография, 2019. — 291 с.

ISBN 978-5-907053-34-2

DOI 10.31600/978-5-907053-34-2 
Rivers. The apparent fragmentation of the data representing the funeral rites of the second half of the $4^{\text {th }}$ millennium BC in Eastern Anatolia and the Tigris upper basin may be the result of an erroneous strategy of searching for burial grounds within the settlements, while they may turn out to be extramural and even under-barrow.

\title{
SINTIANS/SINDOI AND THEIR POSSIBLE ARCHAEOLOGICAL IDENTIFICATION
}

\author{
Diana S. Gergova \\ National Institute of Archaeology with Museum, Sofia, Bulgaria
}

DOI: $10.31600 / 978-5-907053-34-2-112$

Keywords: Sintians, Sindi, Sindos, sitting deceased, thrones, golden masks, gloves, sandals, Buddhapadda.

The Sintians - sorcerers and speakers of a sacred language, discoverers of harmful herbs, first producers of weapons and pirates, are one of the earliest tribes mentioned in ancient written sources in the Homeric epic already. Their settling in Southwestern Thrace and the Greek islands, which was a result of the great migrations of the Thracian tribes from the north (the CarpathianDanubian area) to the south, the southeast and east in the time around the Trojan war, raises a question about probable common roots of the Sintians and the Sindoi in the Northern Black Sea coast. Can we distinguish the culture of the Sintians from that of the other Thracian tribes, and do they demonstrate similarities with the culture of the Sindoi?

Comparative studies between specific Orphic funerary rites of immortalization in the Late Bronze and Early Iron Age in both Sintika and Sindika are carried out. The burials in a seated position and on a throne, the necropolises around the Thermaic gulf, the core of the territory of the Sintians, and at the Ochrid lake (Sindos, Trebenishte, etc.), together with the finds uncovered there, such as models of thrones, tables and chariots, gold masks, pectorals, gold gloves and sandals, are discussed as well in connection with similar phenomena from Sindika and its neighboring areas.

The author argues that an interpretation of these specific burial practices as having roots in the Late Bronze Age of the Carpathian-Danubian basin allows her to suggest that they were practiced by a special group of the priestly or royal-priestly status (Sintians, Sindoi) which preserved them through millennia.

\section{СИНТИ/СИНДЫ \\ И ИХ ВОЗМОЖНАЯ АРХЕОЛОГИЧЕСКАЯ ИДЕНТИФИКАЦИЯ}

\section{Д. Г. Гергова}

Национальньй институт археологии с музеем, София, Болгария

Ключевые слова: синтиане, синды, синдосы, сидящие покойники, престоль, золотые маски, перчатки, сандалии, Буддхападда.

Автор выдвигает гипотезу о возможной археологической идентификации фракийского племени синтов, исходя из специфических черт погребального обряда обессмертивания на их территории в Юго-Западной Фракии, с синдами, обитавшими в Северном Причерноморье. Автор устанавливает происхождение этого обряда в карпато-дунайском регионе в позднем бронзовом веке, а также ставит вопрос о существовании у синтов и синдов особой социальной группы жреческого или царско-жреческого статуса. 